Check for updates

Cite this: RSC Adv., 2018, 8, 19776

\title{
Nickel-foam-supported $\beta-\mathrm{Ni}(\mathrm{OH})_{2}$ as a green anodic catalyst for energy efficient electrooxidative degradation of azo-dye wastewater $\dagger$
}

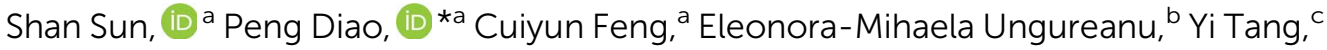 \\ Bin $\mathrm{Hu}^{\mathrm{c}}$ and Qing $\mathrm{Hu}^{* \mathrm{c}}$
}

Electrochemical oxidative degradation (EOD) is a particularly promising technique for removing organic pollutants from wastewater. However, due to the high overpotential of EOD in conventional anode materials, the energy cost of EOD is usually very high, which greatly promotes the search for highly active, stable, and energy-efficient anodic catalysts. Herein, we demonstrated that nickel-foamsupported (NF-supported) $\beta-\mathrm{Ni}(\mathrm{OH})_{2}\left(\mathrm{NF} / \beta-\mathrm{Ni}(\mathrm{OH})_{2}\right)$ prepared via a facile hydrothermal method could be used as an energy efficient anode for EOD. The as-prepared 3D porous $\mathrm{NF} / \beta-\mathrm{Ni}(\mathrm{OH})_{2}$ exhibited high activity toward the electrochemical oxidation of methyl orange $(\mathrm{MO})$ in the low potential region $(<1.07 \mathrm{~V}$ vs. SCE). This property differs greatly from those of the conventional anode materials that require a high positive potential to keep them active for EOD, making $\mathrm{NF} / \beta-\mathrm{Ni}(\mathrm{OH})_{2}$ an energy-efficient and active anode material for EOD. With an oxidation current density of $0.25 \mathrm{~mA} \mathrm{~cm}{ }^{-2}$, the decolorization of $\mathrm{MO}$ was completed within $30 \mathrm{~min}$, and the COD removal after $3 \mathrm{~h}$ of reaction was $63.0 \%$. The normalized energy consumption for the $3 \mathrm{~h}$ degradation of $\mathrm{MO}$ was $22.2 \mathrm{~kW} \mathrm{~h}(\mathrm{~kg} \mathrm{COD})^{-1}$, which is only a fraction of (or even one tenth of) the values reported in the literature. Moreover, NF/ $/ \mathrm{N}-\mathrm{Ni}(\mathrm{OH})_{2}$ had a good stability and recyclability for EOD. No activity decay was observed during $10 \mathrm{~h}$ of EOD and the COD removal remained almost unchanged after four consecutive reaction cycles. We demonstrated experimentally that the $\mathrm{NF} / \beta-\mathrm{Ni}(\mathrm{OH})_{2}$ anode could generate large amounts of hydroxyl radicals and that the oxidation of MO by hydroxyl radicals was the main mechanism during EOD. We believe that this work opens a new avenue for developing highly active and energy-efficient anode materials that can work in the low potential region for EOD.

Received 9th April 2018

Accepted 11th May 2018

DOI: $10.1039 / c 8 r a 03039 a$

rsc.li/rsc-advances

\section{Introduction}

There has been increasing public concern regarding environmental contamination problems arising from rapidly developing industries in the past few decades. ${ }^{1}$ The textile and printing industry is regarded as one of the most polluting sectors due to its massive discharge of dye wastewater, which is usually highly coloured, toxic, and hard to degrade. Among these dyes, azo dyes account for over $70 \%$ of commercial dyestuff, ${ }^{2}$ thereby making them the most important and widely used synthetic dyes in the printing and dyeing industry. Azo dyes contain at least one azo group $(-\mathrm{N}=\mathrm{N}-)$ that is bonded to

${ }^{a}$ School of Materials Science and Engineering, Beihang University, No. 37 Xueyuan Road, Haidian District, Beijing 100191, P. R. China. E-mail: pdiao@buaa.edu.cn; Tel: $+86-10-82339562$

${ }^{b}$ Department of Physical Chemistry and Electrochemistry, Faculty of Applied Chemistry and Materials Science, University Politehnica of Bucharest, 060042, Romania

'Southern University of Science and Technology, Shenzhen, Guangdong, 518055, P. R. China

$\dagger$ Electronic supplementary information (ESI) available. See DOI: $10.1039 / \mathrm{c} 8 \mathrm{ra} 03039 \mathrm{a}$ aromatic moieties containing functional groups such as $-\mathrm{OH}$ and- $\mathrm{SO}_{3} \mathrm{H}^{3}$ A variety of physical, chemical, and biological methods ${ }^{4-6}$ have been developed to treat dye wastewater but most of them have been proven to be ineffective for the removal of dye compounds. In recent years, advanced oxidation processes (AOPs) have been proposed as efficient and emerging alternatives for the treatment of wastewater containing toxic or refractory organic pollutants. ${ }^{7}$ AOPs include many oxidation techniques such as Fenton oxidation, ${ }^{8}$ ozonation, ${ }^{9}$ photocatalytic oxidation, ${ }^{10}$ wet air oxidation, ${ }^{11}$ electrochemical oxidation $^{12}$ and the combination of two oxidation processes. ${ }^{3,7,13,14}$

Among these AOPs, electrochemical oxidation degradation (EOD) has attracted ever increasing interest due to its advantages, such as its high efficiency, ease of manipulation and lower generation of by-products during the removal of organic pollutants. ${ }^{15}$ However, in a typical EOD process, high potentials are required to maintain the high activity of the anode materials toward the oxidation of organic pollutants. Under highly positive potentials, other competing electrochemical oxidation processes such as the oxygen evolution reaction (OER) are also 
promoted, ${ }^{\mathbf{1 6}}$ resulting in an unnecessary loss of energy. In order to suppress the oxidation of water at high potential, great efforts have been made to develop anode materials that have a high overpotential for the OER. For example, $\mathrm{SnO}_{2}$ - and $\mathrm{PbO}_{2}$-based materials have been widely adopted as anodes for the EOD of organic pollutants because both $\mathrm{SnO}_{2}$ and $\mathrm{PbO}_{2}$ exhibit a very high overpotential for water oxidation. ${ }^{17-20}$ However, $\mathrm{SnO}_{2}$ - and $\mathrm{PbO}_{2}$-based anode materials are not environmentally sustainable due to the following facts: $\mathrm{SnO}_{2}$ anodes are often doped with highly toxic $\mathrm{Sb}$ to increase their conductivity and improve their activity for $\mathrm{EOD}^{21}$, and $\mathrm{PbO}_{2}$ anodes may result in the leaching of highly toxic lead ions into solution under anodic oxidation conditions. ${ }^{19,22}$ Boron-doped diamond (BDD), as another anode material with a high OER overpotential, has received great attention due to its green chemical composition and good activity for EOD. ${ }^{15,23}$ However, the preparation of BDD film is economically unfavorable, ${ }^{22}$ and the obtained film usually cracks and detaches from the conducting substrate after long-term EOD, making it unfeasible for large-scale and longterm utilization in practice. ${ }^{7,15}$ Moreover, an intrinsic drawback of anode materials with a high OER overpotential is that they are active only at high potentials, which inevitably leads to a high energy cost. Therefore, it is highly desirable to develop new anode materials with high catalytic activity, good stability and a low energy cost during EOD. Therefore, we aim to develop a new type of anode that can stably work at a low potential to achieve a high EOD efficiency with a low energy consumption.

Compared to other transition metals, nickel has a higher natural abundance and a lower toxicity, which makes it economically feasible for practical applications in industry. ${ }^{24}$ As a typical VIIIB group transition metal, nickel has several valence electrons, which make it an element with variable valence in compounds. Although nickel can exist in the $+2,+3$ and +4 oxidation states, $\mathrm{Ni}(\mathrm{II})$ is the stable valence state of nickel compounds in air and water under most conditions. The high valence states of nickel (e.g. $\mathrm{Ni}(\mathrm{III})$ and $\mathrm{Ni}(\mathrm{Iv})$ ) have strong oxidizing properties, and as a result, $\mathrm{Ni}$ (III) and $\mathrm{Ni}$ (Iv) have shown promise as intermediates in a number of nickel-based catalysts for many oxidation reactions, ${ }^{25-27}$ especially the oxidation of organic compounds such as 4-chlorophenol, ${ }^{28,29}$ urea $^{30}$ and alcohols. ${ }^{31,32}$ Accordingly, it is a good strategy to prepare a highly active nickel-based anode for EOD by growing a condensed film of an $\mathrm{Ni}$ (II) compound on a high-specific-area conducting support. During the EOD, the Ni(II) compound film will be activated via electrochemical oxidization to the high valence states of $\mathrm{Ni}(\mathrm{III})$ and $\mathrm{Ni}(\mathrm{Iv})$, which are highly active for generating hydroxyl radicals ${ }^{33}$ or for directly oxidizing organic pollutants ${ }^{29}$, and will then be reduced back to Ni(II). Ni foam is an excellent support due to its 3D porous network, which provides not only a good conducting substrate but also a large specific area, both of which favour a high efficiency for EOD. ${ }^{34}$ Among nickel(II) compounds, $\mathrm{Ni}(\mathrm{OH})_{2}$ has been demonstrated to be active for the photodegradation of azo dyes. ${ }^{35,36}$ More importantly, $\mathrm{Ni}(\mathrm{OH})_{2}$ exhibits good activity and reversibility during electrochemical oxidation into high valence state $\mathrm{Ni}$ compounds such as $\mathrm{NiOOH} .^{24}$ This property suggests that $\mathrm{Ni}(\mathrm{OH})_{2}$ can act as an electrocatalyst for the EOD of organic pollutants.
The purpose of this paper is to develop a nickel-based catalyst to achieve the EOD of azo dyes with low energy consumption. We report the preparation of a nickel-foam-supported $\beta$ $\mathrm{Ni}(\mathrm{OH})_{2}\left(\mathrm{NF} / \beta-\mathrm{Ni}(\mathrm{OH})_{2}\right)$ anode, which exhibited high catalytic activity toward the EOD of methyl orange (MO) at potentials lower than the water oxidation potential. We demonstrated that the $\left.\mathrm{NF} / \beta-\mathrm{Ni}(\mathrm{OH})_{2}\right)$ anode not only was highly energy-efficient during the galvanostatic degradation of MO but also had an excellent stability and a good recyclability during EOD. We provide solid experimental evidence that a large amount of hydroxyl radicals were electrochemically generated by the NF/ $\beta$ $\mathrm{Ni}(\mathrm{OH})_{2}$ ) anode during EOD, and that the oxidation of MO by hydroxyl radicals was the main mechanism in the degradation of MO. We believe that this work opens a new door to designing anode materials that are highly active toward the anodic degradation of organic pollutants with very low energy consumption.

\section{Experimental section}

\subsection{Materials and chemicals}

Ni foams (NFs, 99.99\% purity, $1.7 \mathrm{~mm}$ thickness, 110 pores per inch (ppi) pore size) were purchased from Lizhiyuan Materials Co., Ltd. Methyl orange (MO) and terephthalic acid were purchased from Sinopharm Chemical Reagent Co., Ltd. and Shanghai Macklin Biochemical Co., Ltd., respectively. Sodium sulfate $\left(\mathrm{Na}_{2} \mathrm{SO}_{4}\right.$, A.R.), sodium carbonate $\left(\mathrm{Na}_{2} \mathrm{CO}_{3}\right.$, A.R.), sodium hydroxide ( $\mathrm{NaOH}$, A.R.), hydrogen peroxide $\left(\mathrm{H}_{2} \mathrm{O}_{2}\right.$, $30 \%)$, ethanol $\left(\mathrm{C}_{2} \mathrm{H}_{5} \mathrm{OH}\right.$, A.R. $)$ and acetone $\left(\mathrm{C}_{3} \mathrm{H}_{6} \mathrm{O}, \mathrm{A} . \mathrm{R}.\right)$ were purchased from Beijing Chemical Reagents Company. All other chemicals were of analytical grade and used without further purification. All aqueous solutions were prepared with ultrapure water $(18 \mathrm{M} \Omega \mathrm{cm})$.

\subsection{Hydrothermal synthesis of $\beta-\mathrm{Ni}(\mathrm{OH})_{2}$ on the surface of nickel foam}

The nickel-foam-supported $\quad \beta-\mathrm{Ni}(\mathrm{OH})_{2} \quad\left(\mathrm{NF} / \beta-\mathrm{Ni}(\mathrm{OH})_{2}\right)$ was prepared via an optimized facile one-step hydrothermal method. In detail, NF $\left(4.0 \times 9.0 \mathrm{~cm}^{2}\right)$ was first rolled into a cylinder and then ultrasonicated successively in acetone, ethanol and deionized water each for $10 \mathrm{~min}$. After being dried in air at $60{ }^{\circ} \mathrm{C}$ for 4 hours, the $\mathrm{NF}$ was introduced into a $50 \mathrm{~mL}$ Teflon-lined stainless-steel autoclave that was filled with $35 \mathrm{~mL}$ $\mathrm{H}_{2} \mathrm{O}_{2}$ aqueous solution ( $30 \mathrm{wt} \%$ concentration). The autoclave was then sealed and maintained at $180{ }^{\circ} \mathrm{C}$ for 1 hour in order to grow $\beta-\mathrm{Ni}(\mathrm{OH})_{2}$ on the surface of the NF. The obtained NF/ $\beta$ $\mathrm{Ni}(\mathrm{OH})_{2}$ was rinsed with copious deionized water and then dried in air at $60{ }^{\circ} \mathrm{C}$ for 4 hours.

\subsection{Electrochemical measurements and electrooxidative degradation}

Linear sweep voltammetry and electrochemical oxidation of MO were performed on a CHI660C workstation (CH Instrument Co.) in a three-electrode cell at room temperature. The cylindrical $\mathrm{NF} / \beta-\mathrm{Ni}(\mathrm{OH})_{2}$ electrode was employed as the working electrode. A Pt mesh and a saturated calomel electrode (SCE) were used as 
the counter and reference electrodes, respectively. For each degradation experiment, $50 \mathrm{~mL}$ MO solution of $0.2 \mathrm{mmol} \mathrm{L}^{-1}$ was employed as the wastewater sample, with $0.05 \mathrm{~mol} \mathrm{~L}^{-1}$ $\mathrm{Na}_{2} \mathrm{SO}_{4}$ (pH 7) as the supporting electrolyte. The electrochemical oxidation degradation (EOD) was conducted under galvanostatic conditions at different current densities from 0.05 to $0.50 \mathrm{~mA} \mathrm{~m}^{-2}$. All the potentials were reported with respect to the SCE, and the corresponding potentials with respect to a reversible hydrogen electrode (RHE) were also given according to the following formula: ${ }^{37}$

$$
E(\mathrm{~V} v s . \mathrm{RHE})=E(\mathrm{~V} v s . \mathrm{SCE})+0.244+0.0591 \mathrm{pH}
$$

\subsection{Characterization and analysis method}

The morphologies of the NF and $\mathrm{NF} / \beta-\mathrm{Ni}(\mathrm{OH})_{2}$ were characterized using a field emission scanning electron microscope (FESEM) (Hitachi S-4800) operating at an accelerating voltage of $10 \mathrm{kV}$. The crystal structures of all the samples were characterized using X-ray diffraction (XRD), which was performed on an $\mathrm{X}$-ray powder diffractometer (Rigaku, rint2000 advance) with $\mathrm{Cu}$ $\mathrm{K} \alpha$ radiation.

Samples of the MO solution were collected at certain time intervals during EOD to monitor the degradation process. In detail, the decolorization rate of the MO solution was characterized using UV-vis absorption spectroscopy (UV2600 spectrophotometer, Tianmei Co., China). The chemical oxygen demand (COD) of the sample solution was measured using the dichromate standard method. ${ }^{6}$ The total organic carbon (TOC) measurements were carried out on a TOC analyzer (TOC-VCPN, Shimadzu, Japan).

The decolorization efficiency (or percentage of color removal) was determined using the following expression: ${ }^{38}$

$$
\text { Decolorization efficiency }(\%)=\left(\frac{\mathrm{ABS}_{0}-\mathrm{ABS}_{t}}{\mathrm{ABS}_{0}}\right) \times 100
$$

where $\mathrm{ABS}_{0}$ and $\mathrm{ABS}_{t}$ are the average absorbance at the maximum visible wavelength $\left(\lambda_{\max }\right)$ of the wastewater before and after EOD, respectively.

The current efficiency can then be determined from $\triangle \mathrm{COD}$ $\left(\mathrm{g} \mathrm{dm}^{-3}\right)$ using the equation: ${ }^{7}$

$$
\text { Current efficiency }(\%)=\frac{(\Delta \mathrm{COD}) F V_{\mathrm{s}}}{8 I t} \times 100
$$

where $F$ is the Faraday constant (96487 $\mathrm{C} \mathrm{mol}^{-1}$ ), $V_{\mathrm{s}}$ is the solution volume $\left(\mathrm{dm}^{3}\right), I$ is the applied current (A), 8 is the oxygen equivalent mass $\left(\mathrm{g} \mathrm{eq}^{-1}\right)$ and $t$ is the electrolysis time (s).

Energy consumption was estimated according to the following equation: ${ }^{39}$

$$
\text { Energy consumption }\left(\mathrm{kW} \mathrm{h} \mathrm{m}^{-3}\right)=\frac{E_{\text {cell }} I t}{V_{\mathrm{s}}}
$$

where $E_{\text {cell }}$ is the average potential difference of the cell (V), $t$ is the EOD time $(\mathrm{h})$ and $V_{\mathrm{s}}$ is the solution volume $(\mathrm{L})$. As is well known, energy consumption is proportional to the amount of organic pollutant in solution. Therefore, to make comparison easier between different EOD methods, it is necessary to normalize the energy consumption. The normalized energy consumption (NEC) can be expressed as follows when COD removal $(\Delta \mathrm{COD})$ is known: ${ }^{3}$

$$
\mathrm{NEC}_{\mathrm{COD}}\left(\mathrm{kW} \mathrm{h}(\mathrm{kg} \mathrm{TOC})^{-1}\right)=\frac{E_{\text {cell }} I t}{V_{\mathrm{s}}(\Delta \mathrm{COD})}
$$

The mechanism of the EOD by the $\mathrm{NF} / \beta-\mathrm{Ni}(\mathrm{OH})_{2}$ electrode was analyzed using a fluorescence spectrophotometer (Hitachi, Japan) using terephthalic acid as the hydroxyl radical scavenger. In detail, terephthalic acid was dissolved in $0.002 \mathrm{~mol} \mathrm{~L}^{-1}$ $\mathrm{NaOH}$ solution to give a final concentration of $5 \times$ $10^{-4}$ mol L ${ }^{-1}$. Then $\mathrm{Na}_{2} \mathrm{SO}_{4}$ was dissolved in the resulting solution with a concentration of $0.05 \mathrm{~mol} \mathrm{~L}^{-1}$ and the $\mathrm{pH}$ of the solution was adjusted to 7 . The $\mathrm{NF} / \beta-\mathrm{Ni}(\mathrm{OH})_{2}$ electrode was employed as the working electrode and the galvanostatic oxidation was carried out at $0.25 \mathrm{~mA} \mathrm{~cm}^{-2}$ in $0.05 \mathrm{~mol} \mathrm{~L}^{-1}$ $\mathrm{Na}_{2} \mathrm{SO}_{4}(\mathrm{pH} 7)$ solution containing $5 \times 10^{-4} \mathrm{M}$ terephthalic acid. During the experiment, the solution sample was taken out every $5 \mathrm{~min}$ to measure the fluorescence emission spectrum (excitation at $315 \mathrm{~nm}$ ).

\section{Results and discussion}

\subsection{Microstructure and crystal structure of $\mathrm{NF} / \mathrm{\beta}-\mathrm{Ni}(\mathrm{OH})_{2}$}

Fig. 1 shows the typical SEM images of the pristine NF and the as-prepared $\mathrm{NF} / \beta-\mathrm{Ni}(\mathrm{OH})_{2}$. The pristine $\mathrm{NF}$ had a $3 \mathrm{D}$ porous network structure with a pore size ranging from 60 to $300 \mu \mathrm{m}$ (Fig. 1a and S1 in the ESI $\dagger$ ). The high magnification SEM image (Fig. 1b) reveals that the surface of the NF was quite smooth. After the hydrothermal reaction in $\mathrm{H}_{2} \mathrm{O}_{2}$ solution, the surface of the NF was coated with a relatively rough film, which was composed of densely stacked spindle-like $\beta-\mathrm{Ni}(\mathrm{OH})_{2}$ nanorods, as shown in Fig. 1c and d. Statistical analysis of the SEM images reveals that the spindle-like nanorods had an average length of $280 \pm 30 \mathrm{~nm}$ and a width of $160 \pm 30 \mathrm{~nm}$ (see Fig. S2 in the

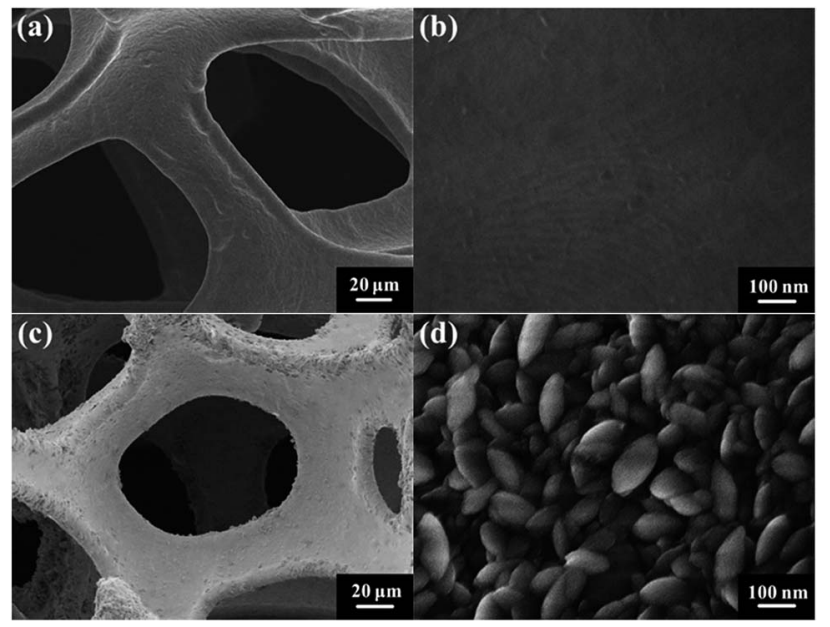

Fig. 1 Typical SEM images of the nickel foam (a) and (b), and NF/ $\beta$ $\mathrm{Ni}(\mathrm{OH})_{2}(\mathrm{c})$ and $(\mathrm{d})$. 
ESI $\dagger)$. These spindle-like $\beta-\mathrm{Ni}(\mathrm{OH})_{2}$ nanorods formed a compact film that had such a strong adhesion to the NF that it was even difficult to scratch them off the surface of the NF.

The crystal structure of the $\mathrm{NF} / \beta-\mathrm{Ni}(\mathrm{OH})_{2}$ electrode was characterized using X-ray diffraction (XRD) and the corresponding XRD pattern is shown in Fig. 2. Along with the strong peaks representing the Ni foam substrate (JCPDS card no. 040850), the new diffraction peaks located at $19.3^{\circ}, 33.1^{\circ}$ and $38.5^{\circ}$ are indexed to the hexagonal phase of $\beta-\mathrm{Ni}(\mathrm{OH})_{2}$ (JCPDS card no. 14-0117), indicating that the spindle-like nanorods observed in Fig. 1d are $\beta-\mathrm{Ni}(\mathrm{OH})_{2}$ particles. Moreover, no peaks of $\alpha$ $\mathrm{Ni}(\mathrm{OH})_{2}$ can be identified in the XRD pattern, suggesting that pure $\beta-\mathrm{Ni}(\mathrm{OH})_{2}$ film was generated on the surface of the NF during the hydrothermal synthesis in $\mathrm{H}_{2} \mathrm{O}_{2}$ solution. This result is in good agreement with results reported previously. ${ }^{40}$

SEM and XRD results confirm the successful growth of $\beta$ $\mathrm{Ni}(\mathrm{OH})_{2}$ on the surface of the NF. In fact, the $3 \mathrm{D}$ porous $\mathrm{NF}$ played three key roles in the preparation of $\mathrm{NF} / \beta-\mathrm{Ni}(\mathrm{OH})_{2}$ to be used as an anode material for EOD. (1) It acted as a Ni source for the in situ hydrothermal growth of $\beta-\mathrm{Ni}(\mathrm{OH})_{2}$ on its surface, and the in situ growth of $\beta-\mathrm{Ni}(\mathrm{OH})_{2}$ on the surface of the NF ensured a strong adhesion and a good electrical contact between the NF and $\beta-\mathrm{Ni}(\mathrm{OH})_{2}$. (2) It provided a large-surface-area framework for $\beta-\mathrm{Ni}(\mathrm{OH})_{2}$ to grow on, resulting in the formation of a $3 \mathrm{D}$ porous $\mathrm{NF} / \beta-\mathrm{Ni}(\mathrm{OH})_{2}$ anode that had a large electrode/solution interface for the EOD of organic pollutants. (3) It provided an electrically well-connected network system, guaranteeing that all the $\beta-\mathrm{Ni}(\mathrm{OH})_{2}$ grown on the NF surface was electrochemically active for EOD.

\subsection{Electrochemical oxidative degradation of methyl orange}

The current density $(J)$ at the applied potential is a key parameter for the electrooxidative removal of organic pollutants because it reflects the catalytic activity of the electrode. Accordingly, linear sweep voltammetric (LSV) measurements were carried out to examine the electrochemical activity of the $\mathrm{NF} / \beta-\mathrm{Ni}(\mathrm{OH})_{2}$ electrode toward MO oxidation. Fig. 3a shows the current-potential responses of the $\mathrm{NF} / \beta-\mathrm{Ni}(\mathrm{OH})_{2}$ electrode in

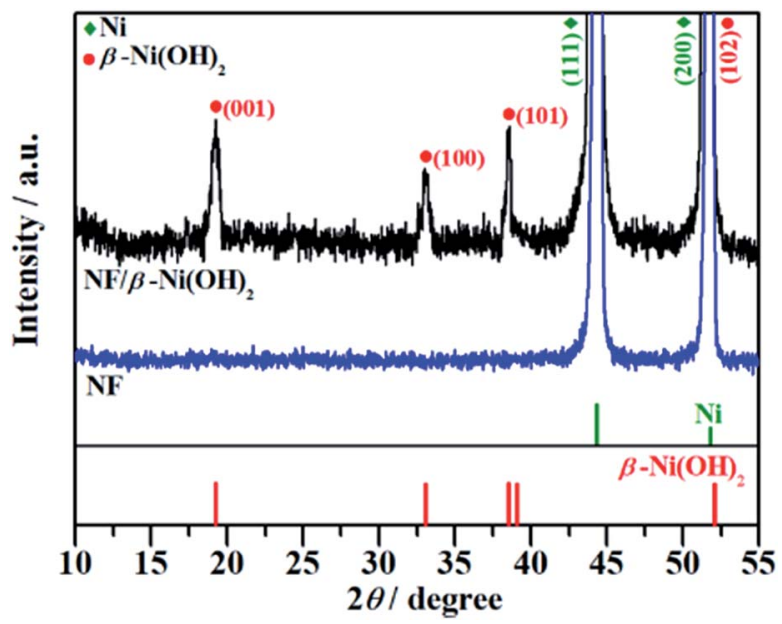

Fig. 2 XRD patterns of the nickel foam (NF) and $\mathrm{NF} / \beta-\mathrm{Ni}(\mathrm{OH})_{2}$.

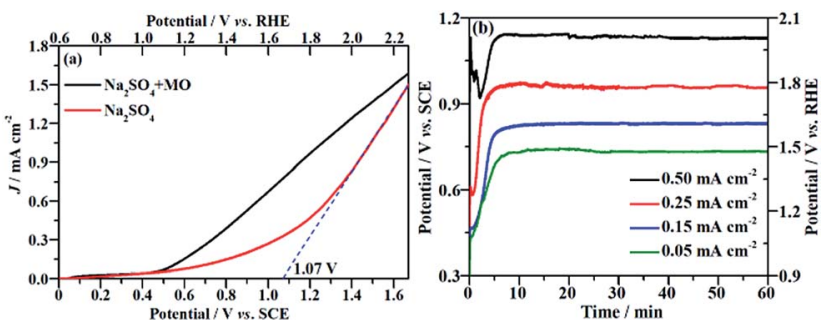

Fig. 3 (a) Linear sweep voltammetric curves of the $N F / \beta-N i(O H)_{2}$ electrode in a $0.05 \mathrm{~mol} \mathrm{~L}^{-1} \mathrm{Na}_{2} \mathrm{SO}_{4}$ electrolyte with and without $0.2 \mathrm{mmol} \mathrm{L}{ }^{-1} \mathrm{MO}$. Potential sweep rate: $10 \mathrm{mV} \mathrm{s}^{-1}$. (b) Chronopotentiometric potential-time curves at different current densities.

the background electrolyte ( $\left.50 \mathrm{mM} \mathrm{Na}_{2} \mathrm{SO}_{4}\right)$ and MO-containing electrolyte $\left(0.2 \mathrm{mM} \mathrm{MO}\right.$ and $\left.50 \mathrm{mM} \mathrm{Na} \mathrm{SO}_{4}\right)$. As can be seen in Fig. 3a, the $\mathrm{NF} / \mathrm{\beta}-\mathrm{Ni}(\mathrm{OH})_{2}$ electrode showed a very small oxidation $J$ in the blank $\mathrm{Na}_{2} \mathrm{SO}_{4}$ solution when the applied potential was lower than $1.0 \mathrm{~V} v$ s. SCE, suggesting that the $\mathrm{NF} / \beta-\mathrm{Ni}(\mathrm{OH})_{2}$ electrode was not active toward the OER in this potential region. When the applied potential was over $1.10 \mathrm{~V} v s$. SCE $(1.70 \mathrm{~V} v s$. RHE), a steep increase in $J$ can be observed in the blank solution as shown in Fig. 3a, indicating that the oxygen evolution reaction (OER) occurred intensively. ${ }^{41}$ To estimate the onset potential for the OER, the tangent was extended to the lateral axis from the high potential region, ${ }^{42}$ and an intercept of $c a .1 .07 \mathrm{~V}$ vs. SCE (1.67 V vs. RHE) was obtained, suggesting that significant occurrence of the OER started at this potential. In this work, the potential region smaller than $1.07 \mathrm{~V} v s$. SCE is referred to as the low potential region.

Fig. 3a also shows that when MO was present in the solution, an obvious oxidation $J$ was observed with an onset potential of ca. $0.50 \mathrm{~V} v s$. SCE. By comparing the LSV curves with and without MO, it is safe to conclude that the electrochemical oxidation of MO commenced at $0.50 \mathrm{~V} v s$. SCE. This result implies that the $\mathrm{NF} / \beta-\mathrm{Ni}(\mathrm{OH})_{2}$ electrode exhibited a remarkable catalytic activity toward MO oxidation even in the low potential region from $0.50 \mathrm{~V}$ to $1.07 \mathrm{~V}$ vs. SCE. Ideally, during electrochemical degradation, the applied potential should remain below the water oxidation onset potential (1.07 V vs. SCE) to reduce the competition of the OER and so improve the current efficiency and energy efficiency. ${ }^{7}$ Fig. 3a clearly shows that the oxidation current in the low potential region (from $0.50 \mathrm{~V}$ to $1.07 \mathrm{~V} v s$. SCE) mainly came from the oxidation of MO because the OER did not occur significantly in this potential region. Therefore, it is possible to electrochemically degrade MO on the $\mathrm{NF} / \beta-\mathrm{Ni}(\mathrm{OH})_{2}$ anode while avoiding the occurrence of the OER in the low potential region.

The EOD of organic pollutants is usually carried out at a constant $J^{3}$ because a constant $J$ means a fixed electrochemical reaction rate, which is convenient for industrial application. Fig. $3 \mathrm{~b}$ shows the potential response with time during the galvanostatic measurements at different $J$ values of $0.05,0.15,0.25$ and $0.50 \mathrm{~mA} \mathrm{~cm}^{-2}$. As shown in Fig. 3b, the smaller the applied value of $J$ is, the lower the stable potential will be. When $J$ is less than or equal to $0.25 \mathrm{~mA} \mathrm{~cm}^{-2}$, the stable potential is lower than $1.07 \mathrm{~V}$, implying that water oxidation does not significantly 
occur at these current densities. However, at a $J$ value of $0.50 \mathrm{~mA}$ $\mathrm{cm}^{-2}$, the stable potential $(c a .1 .10 \mathrm{~V})$ falls into the region in which the OER starts at the NF/ $\beta-\mathrm{Ni}(\mathrm{OH})_{2}$ anode. In fact, the slow but obvious formation and evolution of $\mathrm{O}_{2}$ bubbles was observed during galvanostatic degradation at $0.50 \mathrm{~mA} \mathrm{~cm}$. Therefore, in this work, we employed three small constant current densities of $0.05,0.15$ and $0.25 \mathrm{~mA} \mathrm{~cm}^{-2}$ to avoid the OER and to demonstrate the high electrocatalytic activity of the $\mathrm{NF} / \beta-\mathrm{Ni}(\mathrm{OH})_{2}$ anode toward the degradation of MO with very low energy consumption.

\subsection{Electrochemical oxidative degradation of MO at constant current density}

The characteristic absorption peak of MO that is attributed to the conjugated structure of azo benzene is located at $464 \mathrm{~nm}$ in the UV-vis spectrum. ${ }^{43}$ During the galvanostatic degradation, the decolorization of MO was monitored using UV-vis spectroscopy because the intensity of the absorption peak represents the concentration of MO. Fig. $4 \mathrm{a}-\mathrm{c}$ present the evolution of the UV-vis spectra as a function of time during EOD at a constant current density of $0.05,0.15$ and $0.25 \mathrm{~mA} \mathrm{~cm}^{-2}$, respectively. The absorption peak of MO decreased with degradation time at all current densities, and total decolorization was achieved within 60 min even at a current density as low as $0.05 \mathrm{~mA} \mathrm{~cm}^{-2}$. The decolorization efficiency at any time can be calculated from eqn (2) using the absorbance at $\lambda=464 \mathrm{~nm}$ in the UV-vis spectra. Fig. 4d shows the variation of the decolorization efficiency as a function of degradation time. The electrochemical decolorization rate depended significantly on the applied current density $J$, and a higher value of applied $J$ resulted in a larger decolorization rate. With a constant $J$ of 0.05 $\mathrm{mA} \mathrm{cm} \mathrm{cm}^{-2}$, it took only $30 \mathrm{~min}$ to achieve $85 \%$ decolorization efficiency, whereas it took $12 \mathrm{~min}$ to reach the same efficiency with a constant $J$ of $0.15 \mathrm{~mA} \mathrm{~cm}{ }^{-2}$. Surprisingly, it took only $6 \mathrm{~min}$ when the applied $J$ was $0.25 \mathrm{~mA} \mathrm{~cm}^{-2}$. Fig. $4 \mathrm{~d}$ also demonstrates that total decolorization could be completed within $30 \mathrm{~min}$ as long as the applied $J$ was higher than $0.15 \mathrm{~mA}$ $\mathrm{cm}^{-2}$. This result reveals that the $\mathrm{NF} / \beta-\mathrm{Ni}(\mathrm{OH})_{2}$ anode had a high catalytic activity toward the electrooxidative decolorization of MO. It should be pointed out herein that, due to the fast decolorization at $0.25 \mathrm{~mA} \mathrm{~cm}{ }^{-2}$, there is little room to further improve the decolorization rate by increasing the current
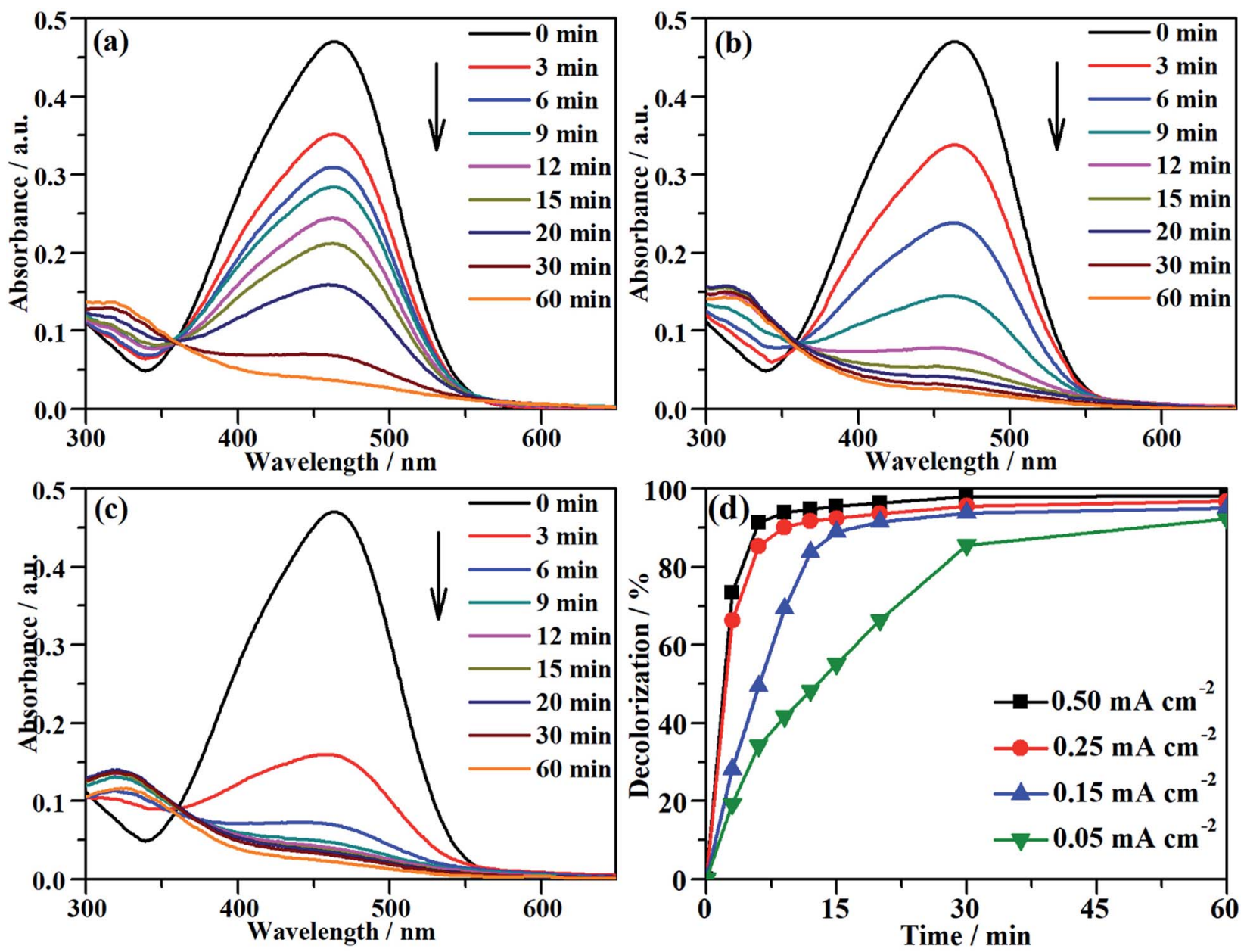

Fig. 4 The variation of the UV-vis spectra of the $M O$ solution as a function of time during galvanostatic degradation at the different current densities of (a) $0.05 \mathrm{~mA} \mathrm{~cm}^{-2}$, (b) $0.15 \mathrm{~mA} \mathrm{~cm}^{-2}$ and (c) $0.25 \mathrm{~mA} \mathrm{~cm}^{-2}$. (d) Dependence of decolorization on time during EOD at different current densities. The galvanostatic degradation was conducted in a $0.2 \mathrm{mmol} \mathrm{L} \mathrm{L}^{-1} \mathrm{MO}$ solution containing $0.05 \mathrm{~mol} \mathrm{~L}^{-1} \mathrm{Na}_{2} \mathrm{SO}_{4}$ at room temperature. 
density. In fact, as shown in Fig. 4d, when $J$ was increased to $0.50 \mathrm{~mA} \mathrm{~cm}^{-2}$, it still took ca. $5 \mathrm{~min}$ to achieve a decolorization efficiency of $85 \%$. Moreover, as shown in Fig. 3, when the applied $J$ was increased to $0.50 \mathrm{~mA} \mathrm{~cm}{ }^{-2}$, the competing side reaction (OER) occurred significantly, which inevitably increased the unnecessary energy consumption. Therefore, in this work, we employed $0.25 \mathrm{~mA} \mathrm{~cm}^{-2}$ as the highest $J$ for the following experiments: galvanostatic degradation, recycling tests, stability measurements, and mechanism analyzing experiments as well.

Although the decolorization efficiency is one of the key parameters for evaluating the degradation of dye pollutants, it cannot be taken as evidence of mineralization because decolorization only relates to the cleavage of the conjugated structure. To further investigate the capability for mineralization, the COD and TOC levels of the MO solution were monitored and the results are shown in Fig. 5. Under a certain current density, both COD and TOC removal continue to increase over time, demonstrating that the $\mathrm{NF} / \beta-\mathrm{Ni}(\mathrm{OH})_{2}$ electrode is capable of not only decolorizing but also mineralizing MO. As the current density was increased from 0.05 to $0.25 \mathrm{~mA} \mathrm{~cm}{ }^{-2}$, both COD
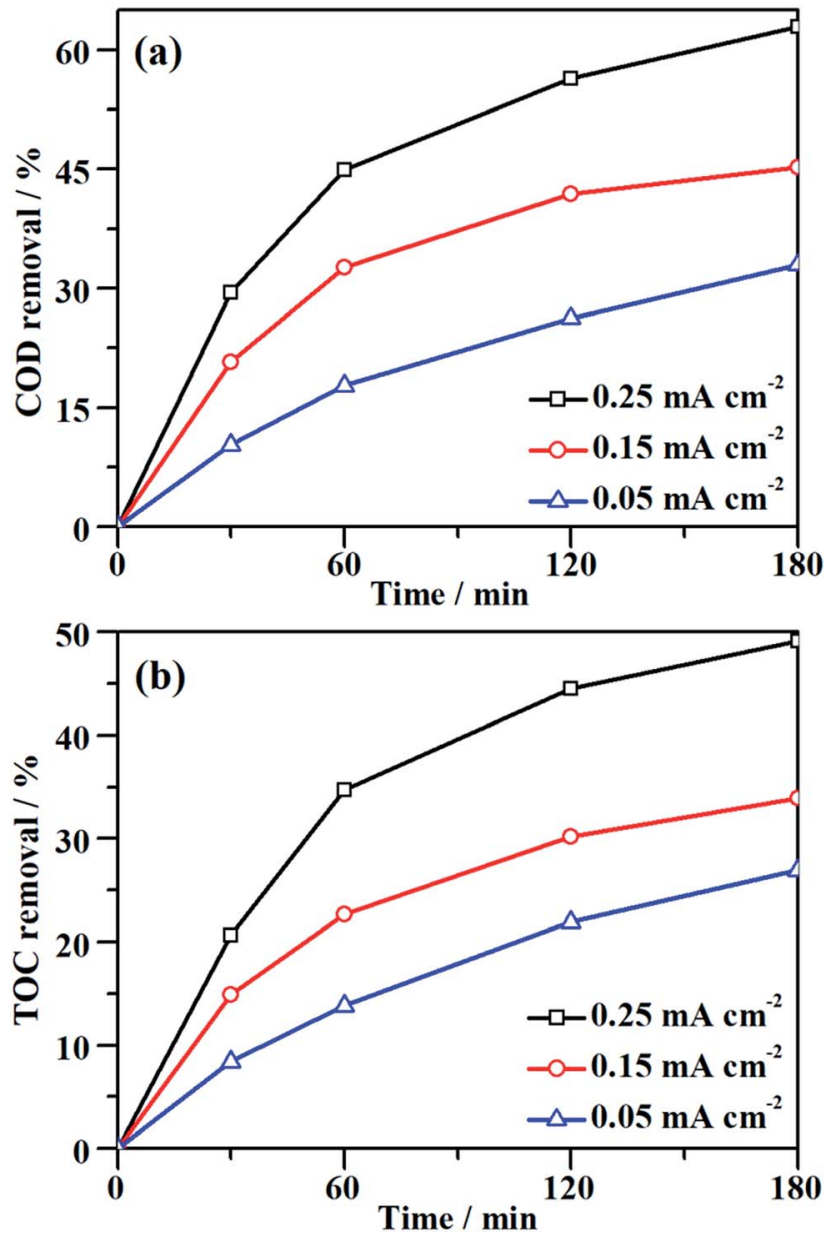

Fig. 5 Variation of (a) COD removal and (b) TOC removal as a function of time during galvanostatic degradation at different current densities. The galvanostatic degradation was conducted in a $0.2 \mathrm{mmol} \mathrm{L}^{-1} \mathrm{MO}$ solution containing $0.05 \mathrm{~mol} \mathrm{~L}^{-1} \mathrm{Na}_{2} \mathrm{SO}_{4}$ at room temperature. and TOC removal in the same time interval increased. After $3 \mathrm{~h}$ of degradation at $0.25 \mathrm{~mA} \mathrm{~cm}^{-2}, 63.0 \% \mathrm{COD}$ removal and $49.1 \%$ TOC removal were achieved. According to eqn (3), the calculated current efficiency after $0.5 \mathrm{~h}$ and $3 \mathrm{~h}$ was $44.9 \%$ and $26.4 \%$, respectively. These values are relatively high for electrooxidation degradation, indicating the superior activity of the $\mathrm{NF} / \beta-\mathrm{Ni}(\mathrm{OH})_{2}$ electrode. These results illustrate that the $\mathrm{NF} / \beta$ $\mathrm{Ni}(\mathrm{OH})_{2}$ electrode is highly active for the mineralization of $\mathrm{MO}$ even in the low potential region.

\subsection{Stability and recyclability of the $\mathrm{NF} / \beta-\mathrm{Ni}(\mathrm{OH})_{2}$ electrode for EOD}

Long-term durability and recyclability are two crucial parameters that determine the performance of the $\mathrm{NF} / \beta-\mathrm{Ni}(\mathrm{OH})_{2}$ electrode in practical applications. To examine the stability of the electrode during the electrocatalytic process, EOD measurements were continuously carried out at $0.25 \mathrm{~mA} \mathrm{~cm}^{-2}$ for $10 \mathrm{~h}$ and Fig. 6 shows the corresponding potential-time curve. As is well known, when the activity of an anode decays during galvanostatic oxidation, the stable potential will increase with reaction time. As shown in Fig. 6, during the entire galvanostatic degradation, the potential was stabilized at $c a .0 .93 \mathrm{~V} v$ s. SCE. The SEM images of $\mathrm{NF} / \beta-\mathrm{Ni}(\mathrm{OH})_{2}$ after EOD are presented in Fig. 7. Compared with $\mathrm{NF} / \beta-\mathrm{Ni}(\mathrm{OH})_{2}$ before EOD as shown in Fig. 1c and d, both low and high magnification SEM images indicate clearly that after 3 hours of degradation, the morphology does not change and the spindle-like nanorods remain intact, indicating that $\mathrm{NF} / \beta-\mathrm{Ni}(\mathrm{OH})_{2}$ had an excellent stability for EOD. Fig. 8a shows the COD removal of MO in four consecutive runs of galvanostatic degradation that were conducted at $0.25 \mathrm{~mA} \mathrm{~cm} \mathrm{~cm}^{-2}$ each for $3 \mathrm{~h}$. The potential-time responses of the four degradation cycles are shown in Fig. 8b. The COD removal remained nearly unchanged even after four reaction cycles (Fig. 8a), and the stable potentials of each EOD cycle were quite similar to each other (Fig. 8b). These results provide solid evidence that the $\mathrm{NF} / \beta-\mathrm{Ni}(\mathrm{OH})_{2}$ electrode has a good recyclability for the EOD of MO.

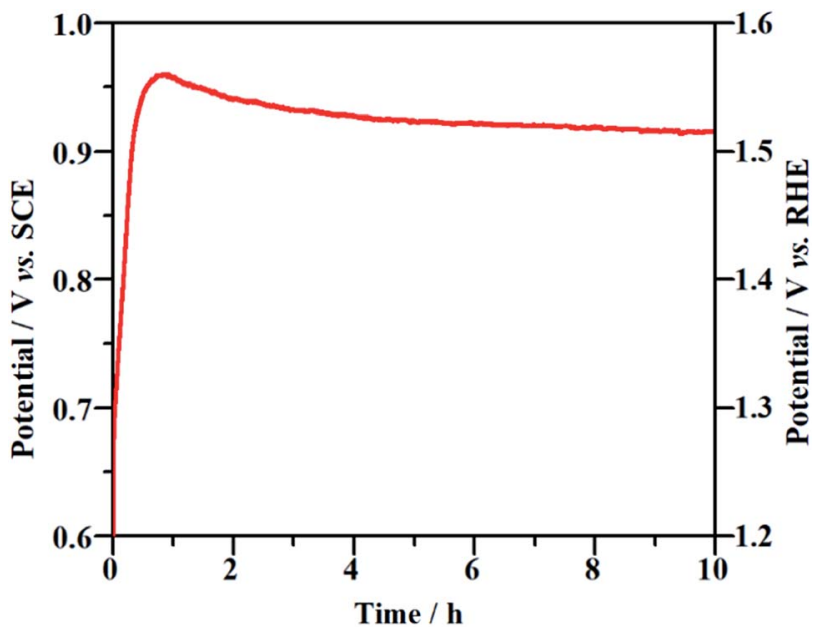

Fig. 6 Chronopotentiometric potential-time curve of the NF/ $\beta$ $\mathrm{Ni}(\mathrm{OH})_{2}$ electrode at a current density of $0.25 \mathrm{~mA} \mathrm{~cm}^{-2}$. 


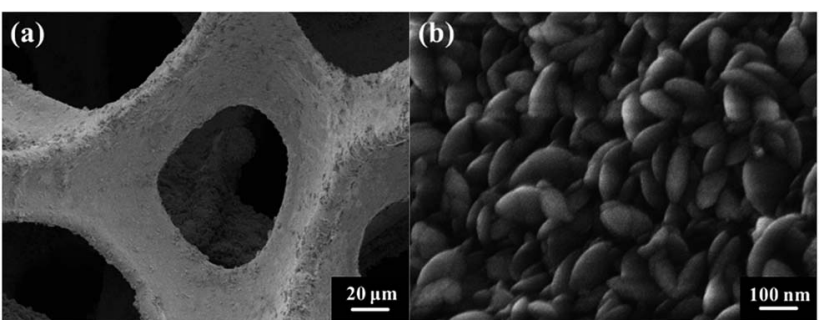

Fig. 7 Low (a) and high (b) magnification SEM images of $\mathrm{NF} / \beta-\mathrm{Ni}(\mathrm{OH})_{2}$ after electrooxidative degradation.
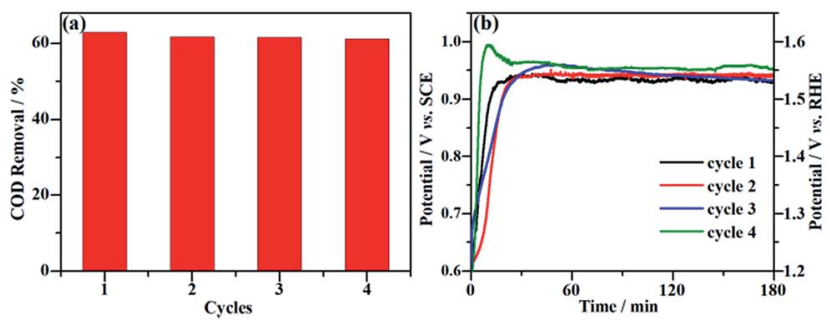

Fig. 8 Recyclability of the $\mathrm{NF} / \beta-\mathrm{Ni}(\mathrm{OH})_{2}$ electrode for the galvanostatic degradation of $\mathrm{MO}$. (a) Percentage of COD removal of $\mathrm{MO}$ for four consecutive degradation cycles. (b) Corresponding potentialtime response for each degradation cycle.

\subsection{Energy consumption analysis}

Energy consumption is an essential parameter to assess the viability of an electrochemical method for the degradation of organic pollutants in the viewpoint of industrial applications. The energy consumption of EOD can be calculated out on the basis of eqn (3). In this work, when EOD was conducted at $0.25 \mathrm{~mA} \mathrm{~cm} \mathrm{~cm}^{2}$ for $3 \mathrm{~h}, 63 \%$ COD removal were obtained on the $\mathrm{NF} / \beta-\mathrm{Ni}(\mathrm{OH})_{2}$ electrode at the expense of an energy consumption of only $1.21 \mathrm{~kW} \mathrm{~h} \mathrm{~m}^{-3}$. To rule out the effect of the organic pollutant amount on the energy consumption and to make an easy comparison with the results reported in literature, we normalized energy consumption by $\mathrm{COD}$ removal $\left(\mathrm{NEC}_{\mathrm{COD}}\right)$ according to eqn (4). The values of $\mathrm{NEC}_{\mathrm{COD}}, \mathrm{COD}$ and TOC removal efficiencies obtained on the $\mathrm{NF} / \beta-\mathrm{Ni}(\mathrm{OH})_{2}$ electrode in this work and on other anode materials reported in literature were listed in Table 1 for comparison. By using the $N F / \beta$ $\mathrm{Ni}(\mathrm{OH})_{2}$ anode, we obtained an $\mathrm{NEC}_{\mathrm{COD}}$ value of $22.2 \mathrm{~kW} \mathrm{~h}$ $(\mathrm{kg} \mathrm{COD})^{-1}$, which is remarkably smaller than those reported in literature. The lowest energy consumption per unit mass of COD or TOC was ascribed to the high electrocatalytic activity of $\mathrm{NF} / \beta-\mathrm{Ni}(\mathrm{OH})_{2}$ for $\mathrm{MO}$ oxidation at low potential region. It should be pointed out herein that, at high potential region, some of the catalysts such as BDD exhibited a higher activity toward degradation of organic dyes than the $\mathrm{NF} / \beta-\mathrm{Ni}(\mathrm{OH})_{2}$ electrode. ${ }^{\mathbf{4 4 , 4 5}}$ However, considering the low cost and high energy efficiency, our $\mathrm{NF} / \beta-\mathrm{Ni}(\mathrm{OH})_{2}$ electrode is still highly competitive to other electrodes for EOD. In the light of results above, $\mathrm{NF} / \mathrm{\beta}-\mathrm{Ni}(\mathrm{OH})_{2}$ may become a promising candidate electrode material, whose electrochemical properties make it more cost effective than BDD and more environmentally friendly than $\mathrm{PbO}_{2}$ and $\mathrm{SnO}_{2}$ based electrodes.

\subsection{Mechanism of the electrooxidative degradation of MO on the $\mathrm{NF} / \boldsymbol{\beta}-\mathrm{Ni}(\mathrm{OH})_{2}$ electrode}

The EOD of organic compounds involves the following two routes: direct oxidation at the electrode surface, and indirect oxidation in homogeneous solution by hydroxyl radicals $\left({ }^{\circ} \mathrm{OH}\right)$ that are generated on the electrode. ${ }^{\mathbf{1 , 1 6}}$ To determine which of the above routes is the main mechanism on the $\mathrm{NF} / \beta-\mathrm{Ni}(\mathrm{OH})_{2}$ anode, we added a hydroxyl radical scavenger to capture the electrochemically generated ${ }^{\circ} \mathrm{OH}$. In this work, terephthalic acid was employed as the hydroxyl radical scavenger because it

Table 1 Percentage of COD and TOC removal and the normalized energy consumption during EOD of dye solutions using different electrodes

\begin{tabular}{|c|c|c|c|c|c|c|c|c|}
\hline $\mathrm{NF} / \beta-\mathrm{Ni}(\mathrm{OH})_{2}$ & Methyl orange & 0.25 & 3 & 63.0 & 49.1 & 1.21 & 22.2 & This work \\
\hline $\mathrm{PbO}_{2}$ & Methyl orange & $0.6^{a}$ & 4 & - & 60 & 34.7 & - & 46 \\
\hline $\mathrm{PbO}_{2}$ & Basic yellow 2 & 50 & 4 & 95 & - & 26.13 & 183 & 47 \\
\hline BDD & Methyl orange & 31 & 2.3 & - & 60.3 & 7.66 & - & 48 \\
\hline $\mathrm{Nb} / \mathrm{BDD}$ & Real wastewater & 5 & 5 & 93 & - & 30 & 108 & 50 \\
\hline $\mathrm{Si} / \mathrm{BDD}$ & Direct black 22 & 30 & - & 65 & - & 115 & 816 & 51 \\
\hline $\mathrm{Pt}$ & Methyl red & 60 & 2.5 & - & 25 & 56.4 & - & 52 \\
\hline $\mathrm{Ti} / \mathrm{Pt}$ & Methylene blue & 50 & 6 & 75 & - & 33.6 & 279 & 38 \\
\hline $\mathrm{Ti} / \mathrm{Ru}_{0.3} \mathrm{Ti}_{0.7} \mathrm{O}_{2}$ & Methyl red & 30 & 2.5 & - & 100 & 11 & - & 53 \\
\hline GAC/ATOT & Rhodamine B & 60 & 1 & 65 & - & 39 & 400 & 54 \\
\hline
\end{tabular}

${ }^{a}$ Current (A). 

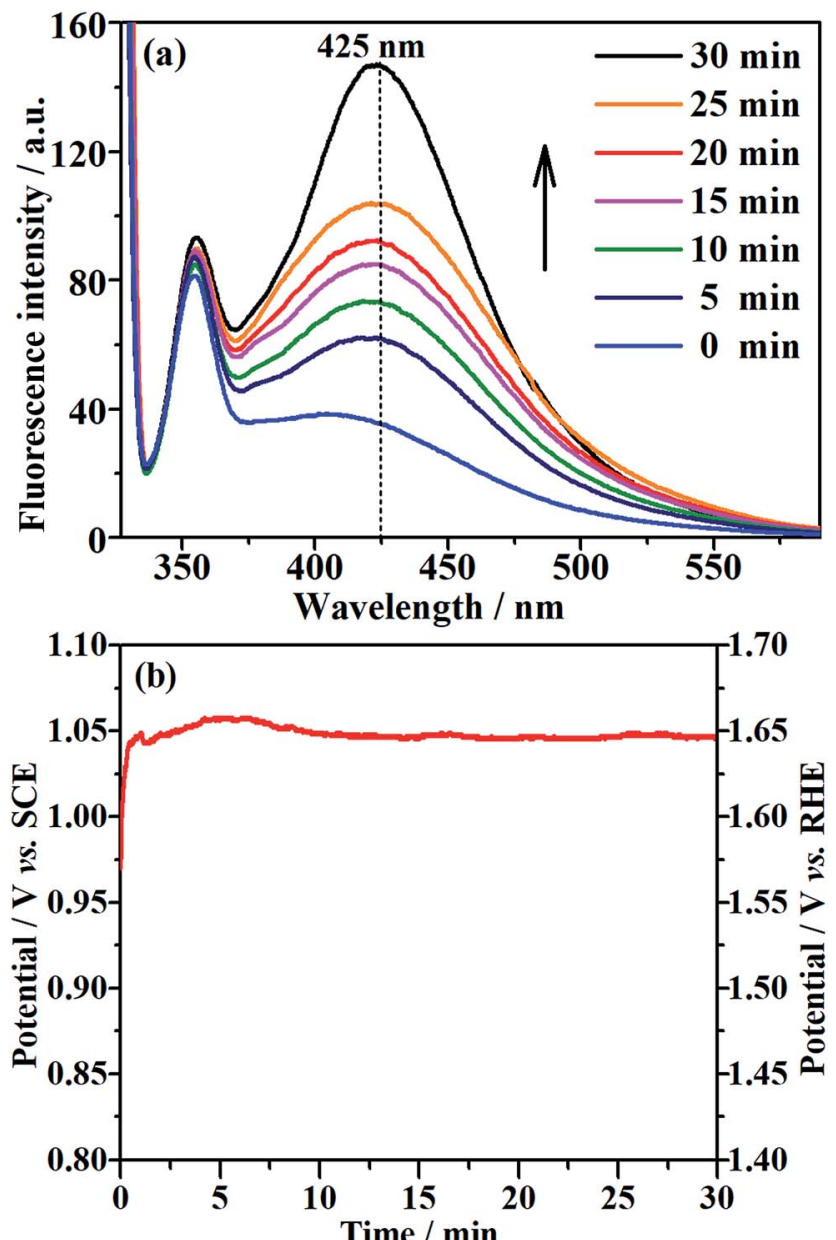

Fig. 9 (a) Fluorescence spectral changes observed during galvanostatic oxidation at a current density of $0.25 \mathrm{~mA} \mathrm{~cm}^{-2}$ in $0.05 \mathrm{~mol} \mathrm{~L}^{-1}$ $\mathrm{Na}_{2} \mathrm{SO}_{4}\left(\mathrm{pH}\right.$ 7) containing $5 \times 10^{-4} \mathrm{~mol} \mathrm{~L}^{-1}$ terephthalic acid at room temperature. (b) The corresponding potential-time curve during galvanostatic oxidation.
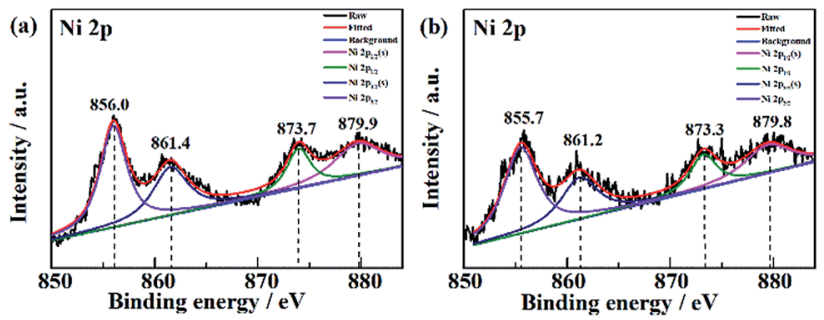

Fig. 10 High resolution $\mathrm{Ni} 2 \mathrm{p}$ spectra of $\mathrm{NF} / \mathrm{\beta}-\mathrm{Ni}(\mathrm{OH})_{2}$ (a) before and (b) after electrooxidation of a dye.

combines rapidly with ${ }^{\circ} \mathrm{OH}$ to form a highly fluorescent product (2-hydroxyterephthalic acid) ${ }^{58}$ Therefore, the electrochemically generated ${ }^{\circ} \mathrm{OH}$ could be directly detected using a fluorescence technique and the concentration of ${ }^{\circ} \mathrm{OH}$ could be reflected by the intensity of the fluorescence emission peak of 2-hydroxyterephthalic acid at $425 \mathrm{~nm} .{ }^{58}$ Fig. 9a shows the evolution of the fluorescence emission spectra of the $0.05 \mathrm{~mol} \mathrm{~L}^{-1} \mathrm{Na}_{2} \mathrm{SO}_{4}$ solution (pH 7) containing $5 \times 10^{-4} \mathrm{~mol} \mathrm{~L}^{-1}$ terephthalic acid during galvanostatic oxidation at $0.25 \mathrm{~mA} \mathrm{~cm}{ }^{-2}$. It is clearly seen that the intensity of the fluorescence emission peak at $425 \mathrm{~nm}$ increases with increasing reaction time, which implies that ${ }^{\circ} \mathrm{OH}$ was continuously produced during the galvanostatic oxidation. Fig. $9 \mathrm{~b}$ shows the potential response with time during galvanostatic oxidation at $0.25 \mathrm{~mA} \mathrm{~cm}{ }^{-2}$. It is clearly seen from Fig. $9 \mathrm{~b}$ that the stable potential is only ca. $1.04 \mathrm{~V} v s$. SCE, which falls into the low potential region $(<1.07 \mathrm{~V} v$ s. SCE $)$ discussed in Section 3.2. Fig. 9a and b show solid evidence that, even in low potential regions $\left(<1.07 \mathrm{~V} v\right.$ s. SCE), the $\mathrm{NF} / \beta-\mathrm{Ni}(\mathrm{OH})_{2}$ anode could generate a large amount of hydroxyl radicals, which could diffuse into the bulk of the solution and be captured by terephthalic acid. We believe that this is the origin of why the $\mathrm{NF} / \beta-\mathrm{Ni}(\mathrm{OH})_{2}$ anode exhibits high activity toward EOD at low potential.

The XPS data of $\mathrm{Ni}$ in $\mathrm{NF} / \beta-\mathrm{Ni}(\mathrm{OH})_{2}$ before and after electrooxidation of the dye were obtained and the Ni $2 \mathrm{p}$ highresolution spectra are presented in Fig. 10. In Fig. 10a the two major peaks at $856.0 \mathrm{eV}$ and $873.7 \mathrm{eV}$ correspond to $\mathrm{Ni} 2 \mathrm{p}_{3 / 2}$ and $\mathrm{Ni} 2 \mathrm{p}_{1 / 2}$, respectively, along with the satellite peaks at $861.4 \mathrm{eV}$ and $879.9 \mathrm{eV}$, all of which are consistent with previous reports ${ }^{40}$ and confirm that pure $\mathrm{Ni}(\mathrm{OH})_{2}$ was synthesized on the surface. Fig. 10b shows the XPS data after $3 \mathrm{~h}$ of electrooxidation and we can see that the spectrum has barely changed with only a shift of $\sim 0.3 \mathrm{eV}$ due to the long-term degradation. No peaks of $\mathrm{Ni}^{3+}$ or $\mathrm{Ni}^{4+}$ were detected using XPS. This result is not surprising because the generated high valence state species of $\mathrm{Ni}$ are highly active, so once formed they will instantly react with $\mathrm{H}_{2} \mathrm{O}$ to produce hydroxy radicals and oxidize the organic pollutants. According to the above discussion, it is safe to conclude that indirect oxidation via the electrochemically generated hydroxyl radicals is the main mechanism for the EOD of MO. The NF/ $\beta$ $\mathrm{Ni}(\mathrm{OH})_{2}$ electrocatalyst plays a key role in the EOD of azo-dye, and the main mechanism is as follows. First, $\beta-\mathrm{Ni}(\mathrm{OH})_{2}$ is electrochemically oxidized to high valence state species such as $\mathrm{NiO}(\mathrm{OH})$ or $\mathrm{NiO}(\mathrm{OH})_{2}$ at high positive potential in aqueous solution. Second, the generated $\mathrm{Ni}(\mathrm{III})$ and $\mathrm{Ni}(\mathrm{IV})$ species that are highly active react with $\mathrm{H}_{2} \mathrm{O}$ to produce hydroxy radicals. Finally, the highly oxidative hydroxy radicals attack and degrade the azo-dye molecules. The reactions are as follows:

$$
\begin{gathered}
\beta-\mathrm{Ni}(\mathrm{OH})_{2}-\mathrm{e}^{-} \rightarrow \mathrm{NiO}(\mathrm{OH})+\mathrm{H}^{+} \\
\beta-\mathrm{Ni}(\mathrm{OH})_{2}+\mathrm{H}_{2} \mathrm{O}-2 \mathrm{e}^{-} \rightarrow \mathrm{NiO}(\mathrm{OH})_{2}+2 \mathrm{H}^{+} \\
\mathrm{NiO}(\mathrm{OH})+\mathrm{H}_{2} \mathrm{O} \rightarrow \beta-\mathrm{Ni}(\mathrm{OH})_{2}+\cdot \mathrm{OH} \\
\mathrm{NiO}(\mathrm{OH})_{2}+\mathrm{H}_{2} \mathrm{O} \rightarrow \beta-\mathrm{Ni}(\mathrm{OH})_{2}+2^{\cdot} \mathrm{OH} \\
\cdot \mathrm{OH}+\text { azo-dye } \rightarrow \text { product }
\end{gathered}
$$

\section{Conclusions}

In summary, the nickel-foam-supported $\beta-\mathrm{Ni}(\mathrm{OH})_{2}$ electrode was successfully prepared via a facile hydrothermal method in $\mathrm{H}_{2} \mathrm{O}_{2}$ solution, and the resulting $\mathrm{NF} / \beta-\mathrm{Ni}(\mathrm{OH})_{2}$ electrode had a three-dimensional porous structure with the nickel foam 
being coated with a thin but complete and dense film of $\beta$ $\mathrm{Ni}(\mathrm{OH})_{2}$. The $\mathrm{NF} / \beta-\mathrm{Ni}(\mathrm{OH})_{2}$ electrode exhibited high activity toward the electrooxidative degradation of $\mathrm{MO}$ in the low potential region $(<1.07 \mathrm{~V} v s$. SCE), in which the competing side reaction (water oxidation) did not occur significantly. This property ensured that the $\mathrm{NF} / \beta-\mathrm{Ni}(\mathrm{OH})_{2}$ electrode was energyefficient for the EOD of MO. During galvanostatic degradation at $0.25 \mathrm{~mA} \mathrm{~cm} \mathrm{~cm}^{-2}$, the decolorization of $\mathrm{MO}$ was complete within $30 \mathrm{~min}$. The COD and TOC removals after EOD for $3 \mathrm{~h}$ were $63.0 \%$ and $49.1 \%$, respectively, with a normalized energy consumption of $22.2 \mathrm{~kW} \mathrm{~h}(\mathrm{~kg} \mathrm{COD})^{-1}$. This value is not only the lowest but also just a fraction of (or even one-tenth of) the values reported in the literature. The $\mathrm{NF} / \beta-\mathrm{Ni}(\mathrm{OH})_{2}$ anode showed an excellent stability for EOD, with no sign of activity decay during $10 \mathrm{~h}$ of continuous galvanostatic degradation. In addition, the $\mathrm{NF} / \beta-\mathrm{Ni}(\mathrm{OH})_{2}$ electrode also exhibited a good recyclability for EOD and the COD removal remained almost unchanged after four consecutive cycles of degradation. The mechanism of the EOD on the $\mathrm{NF} / \beta-\mathrm{Ni}(\mathrm{OH})_{2}$ electrode was demonstrated to be the homogeneous indirect oxidation of MO by hydroxyl radicals, which were electrochemically generated during galvanostatic degradation. Owing to its high activity at low potential, high energy efficiency, good stability, and excellent recyclability, $\mathrm{NF} / \beta-\mathrm{Ni}(\mathrm{OH})_{2}$ is a highly competitive anode material for EOD in large scale industrial applications. In addition, this work makes the following combined EOD strategy possible: a long but energy-efficient EOD using $\mathrm{NF} / \beta-\mathrm{Ni}(\mathrm{OH})_{2}$, followed by a short but COD-removal (or TOCremoval) efficient EOD to balance the removal efficiency and energy consumption. Future work to combine this energyefficient $\mathrm{NF} / \beta-\mathrm{Ni}(\mathrm{OH})_{2}$ anode with a highly TOC removing anode is on the way.

\section{Conflicts of interest}

There are no conflicts to declare.

\section{Acknowledgements}

We gratefully acknowledge the financial support of this work by the National Natural Science Foundation of China (NSFC 51672017 and 21173016), Beijing Natural Science Foundation (2142020 and 2151001), and China-Romania InterGovernmental Science \& Technology Cooperation Project (42-26).

\section{Notes and references}

1 C. A. Martinez-Huitle and S. Ferro, Chem. Soc. Rev., 2006, 35(12), 1324-1340.

2 E. Forgacs, T. Cserhati and G. Oros, Environ. Int., 2004, 30(7), 953-971.

3 C. A. Martínez-Huitle and E. Brillas, Appl. Catal., B, 2009, 87(3-4), 105-145.

4 G. TimRobinson and RogerMarchant, PoonamNigam, Bioresour. Technol., 2001, 77(3), 247-255.
5 S. Raghu and C. Ahmed Basha, J. Hazard. Mater., 2007, 149(2), 324-330.

6 N. Daneshvar, H. A. Sorkhabi and M. B. Kasiri, J. Hazard. Mater., 2004, 112(1-2), 55-62.

7 E. Brillas and C. A. Martínez-Huitle, Appl. Catal., B, 2015, 166-167, 603-643.

8 W. H. Scottm Arnold and R. . Harris, Environ. Sci. Technol., 1995, 29, 2083-2089.

9 C. W. M. Wei Chu, Water Res., 2000, 34, 3153-3160.

10 J.-M. Herrmann, Catal. Today, 1999, 53, 115-129.

11 E. L. Dionissios Mantzavinosm, M. Sahibzada, A. G. Livingstonm and I. S. Metcalfe, Water Res., 2000, 34, 1620-1628.

12 C. B. a. G. C. Marco Panizza, Water Res., 2000, 34, 2601-2605. 13 G. Chen, Sep. Purif. Technol., 2004, 38(1), 11-41.

14 X.-f. Lü, H.-r. Ma, Q. Zhang and K. Du, Res. Chem. Intermed., 2012, 39(9), 4189-4203.

15 X. Yu, M. Zhou, Y. Hu, K. Groenen Serrano and F. Yu, Environ. Sci. Pollut. Res., 2014, 21(14), 8417-8431.

16 C. Comninellis, Electrochim. Acta, 1994, 39, 11-12.

17 B. P. Chaplin, Environ. Sci.: Processes Impacts, 2014, 16(6), 1182-1203.

18 X. C. Guohua Zhao, M. Liu, P. Li, Y. Zhang, T. Cao, H. Li, Y. Lei and L. Liu, Environ. Sci. Technol., 2009, 43, 1480-1486.

19 X. Li, D. Pletcher and F. C. Walsh, Chem. Soc. Rev., 2011, 40(7), 3879-3894.

20 H. C. a. D. Johnson, J. Electrochem. Soc., 1990, 137, 10.

21 J. M. Xu, L. Li, S. Wang, H. L. Ding, Y. X. Zhang and G. H. Li, CrystEngComm, 2013, 15(17), 3296.

22 S. You, B. Liu, Y. Gao, Y. Wang, C. Y. Tang, Y. Huang and N. Ren, Electrochim. Acta, 2016, 214, 326-335.

23 E. Brillas, B. Boye, I. Sirés, J. A. Garrido, R. M. a. Rodríguez, C. Arias, P.-L. s. Cabot and C. Comninellis, Electrochim. Acta, 2004, 49(25), 4487-4496.

24 Y. Miao, L. Ouyang, S. Zhou, L. Xu, Z. Yang, M. Xiao and R. Ouyang, Biosens. Bioelectron., 2014, 53, 428-439.

25 G.-F. Chen, T. Y. Ma, Z.-Q. Liu, N. Li, Y.-Z. Su, K. Davey and S.-Z. Qiao, Adv. Funct. Mater., 2016, 26(19), 3314-3323.

26 D. K. Bediako, Y. Surendranath and D. G. Nocera, J. Am. Chem. Soc., 2013, 135(9), 3662-3674.

27 W. Zhu, X. Yue, W. Zhang, S. Yu, Y. Zhang, J. Wang and J. Wang, Chem. Commun., 2016, 52, 1486-1489.

28 Y. H. Wang, K. Y. Chan, X. Y. Li and S. K. So, Chemosphere, 2006, 65(7), 1087-1093.

29 G. I. Cárdenas-Jirón and C. Berríos, Int. J. Quantum Chem., 2008, 108(13), 2586-2594.

30 Z. Yue, S. Yao, Y. Li, W. Zhu, W. Zhang, R. Wang, J. Wang, L. Huang, D. Zhao and J. Wang, Electrochim. Acta, 2018, 268, 211-217.

31 W. S. Cardoso, V. L. N. Dias, W. M. Costa, I. de Araujo Rodrigues, E. P. Marques, A. G. Sousa, J. Boaventura, C. W. B. Bezerra, C. Song, H. Liu, J. Zhang and A. L. B. Marques, J. Appl. Electrochem., 2008, 39(1), 55-64.

32 M. Jafarian, M. Babaee, F. Gobal and M. G. Mahjani, J. Electroanal. Chem., 2011, 652(1-2), 8-12.

33 G. P. Anipsitakis and D. D. Dionysiou, Environ. Sci. Technol., 2004, 38, 3705-3712. 
$34 \mathrm{~W}$. Zhu, R. Zhang, F. Qu, A. M. Asiri and X. Sun, ChemCatChem, 2017, 9, 1721-1743.

35 F. Zhang, Y. J. Liu, Q. H. Liu, Q. Li, H. Li, X. Y. Cai and Y. D. Wang, Mater. Technol., 2013, 28(6), 310-315.

36 S. R. Yousefi, D. Ghanbari, M. Salavati-Niasari and M. Hassanpour, J. Mater. Sci.: Mater. Electron., 2015, 27(2), 1244-1253.

37 Z. Liu, Q. Su, P. Diao and F. Li, A Composite of PyrroleDoped, ChemElectroChem, 2017, 4(9), 2260-2268.

38 G. R. de Oliveira, N. S. Fernandes, J. V. d. Melo, D. R. da Silva, C. Urgeghe and C. A. Martínez-Huitle, Chem. Eng. J., 2011, 168(1), 208-214.

39 E. J. Ruiz, C. Arias, E. Brillas, A. Hernandez-Ramirez and J. M. Peralta-Hernandez, Chemosphere, 2011, 82(4), 495-501.

40 L. Li, J. Xu, J. Lei, J. Zhang, F. McLarnon, Z. Wei, N. Li and F. Pan, J. Mater. Chem. A, 2015, 3(5), 1953-1960.

41 G. Xu, Z. Xu, Z. Shi, L. Pei, S. Yan, Z. Gu and Z. Zou, Silicon, ChemSusChem, 2017, 10(14), 2897-2903.

42 Y. Zhang, B. Cui, Z. Qin, H. Lin and J. Li, Nanoscale, 2013, 5(15), 6826-6833.

43 X. Li, X. Li, W. Yang, X. Chen, W. Li, B. Luo and K. Wang, Electrochim. Acta, 2014, 146, 15-22.

44 C. Zhang, J. Wang, H. Zhou, D. Fu and Z. Gu, Chem. Eng. J., 2010, 161(1-2), 93-98.

45 F. L. Migliorini, N. A. Braga, S. A. Alves, M. R. Lanza, M. R. Baldan and N. G. Ferreira, J. Hazard. Mater., 2011, 192(3), 1683-1689.

46 G. Ramírez, F. J. Recio, P. Herrasti, C. Ponce-de-León and I. Sirés, Electrochim. Acta, 2016, 204, 9-17.
47 E. Hmani, Y. Samet and R. Abdelhédi, Diamond Relat. Mater., 2012, 30, 1-8.

48 C. Ramírez, A. Saldaña, B. Hernández, R. Acero, R. Guerra, S. Garcia-Segura, E. Brillas and J. M. Peralta-Hernández, J. Ind. Eng. Chem., 2013, 19(2), 571-579.

49 C. A. Martínez-Huitle, E. V. dos Santos, D. M. de Araújo and M. Panizza, J. Electroanal. Chem., 2012, 674, 103-107.

50 J. M. Aquino, G. F. Pereira, R. C. Rocha-Filho, N. Bocchi and S. R. Biaggio, J. Hazard. Mater., 2011, 192(3), 1275-1282.

51 J. M. Aquino, M. A. Rodrigo, R. C. Rocha-Filho, C. Sáez and P. Cañizares, Chem. Eng. J., 2012, 184, 221-227.

52 M. G. Tavares, L. V. A. da Silva, A. M. Sales Solano, J. Tonholo, C. A. Martínez-Huitle and C. L. P. S. Zanta, Chem. Eng. J., 2012, 204-206, 141-150.

53 C. C. d. O. Morais, A. J. C. da Silva, M. B. Ferreira, D. M. de Araújo, C. L. P. S. Zanta and S. S. L. Castro, Electrocatalysis, 2013, 4(4), 312-319.

54 X. Li, Y. Wu, W. Zhu, F. Xue, Y. Qian and C. Wang, Electrochim. Acta, 2016, 220, 276-284.

55 J. M. Aquino, R. C. Rocha-Filho, L. A. M. Ruotolo, N. Bocchi and S. R. Biaggio, Chem. Eng. J., 2014, 251, 138-145.

56 M. H. Isa, Desalin. Water Treat., 2013, 53(8), 2260-2265.

57 M. Zhou, L. Liu, Y. Jiao, Q. Wang and Q. Tan, Desalination, 2011, 277(1-3), 201-206.

58 A. Fujishimaa, K.-i. Ishibashi, T. Watanabe and K. Hashimoto, J. Photochem. Photobiol., A, 2000, 134, 139142. 